\title{
Changes in growth caused by climate change and other limiting factors in time affect the optimal equilibrium of close-to-nature forest management
}

\author{
Gerhard Rößiger ${ }^{1 *}$, Ladislav Kulla ${ }^{1}$, Michal Bošel'a ${ }^{2}$ \\ ${ }^{1}$ National Forest Centre - Forest Research Institute Zvolen, T. G. Masaryka 2175/22, SK - 96001 Zvolen, Slovak Republic \\ ${ }^{2}$ Technical University in Zvolen, Faculty of Forestry, T. G. Masaryka 24, SK- 96001 Zvolen, Slovak Republic
}

\begin{abstract}
Historical radial increment data based on tree ring analyses from the close-to-nature experimental forest management unit Smolnícka Osada in Central Slovakia were used for retrospective modelling of changes in forest dynamics to estimate the sensitivity of management planning goals under climate change. Four example years representing historical periods with typically different species-specific patterns of radial increment in mixed beech-fir-spruce forest (1910, 1950, 1980, and 2014) served as virtual starting points for the modelling. An advanced density-dependent matrix transition model was utilised for modelling stand dynamics. An integrated tool for nonlinear financial optimisation searched for an optimal management equilibrium. In addition to transition probabilities adjusted from increment data, some assumptions for changes in ingrowth and mortality related to the increment, as well as a case study concerning the reduced ingrowth changed by game browsing intensity, were tested for modelling more realistic historical ecological conditions. The sensitivity study revealed changes in the optimal management equilibrium represented by optimal basal area, tree species composition, diameter distribution and target harvest diameter over time due to the adapted ecological modelling. The main lesson of the past for the future is to avoid placing too much trust in the simple extrapolation of current trends, such as the observed continual decline in spruce related to climate change, but to be aware of temporal and possibly reversible processes, such as the observed extensive fir recovery after the reduction of air pollution. Tree species diversity appears to be the best option for the uncertain future.
\end{abstract}

Key words: Subplex algorithm; simultaneous nonlinear optimisation; matrix transition model; near-natural forestry; uneven-aged management

Editor: Bohdan Konôpka

\section{Introduction}

Climate change has already increased the temperature in Europe by approximately $1.0^{\circ} \mathrm{C}$ compared with the pre-industrial level and is expected to continue to become more intensive in the next centuries (IPCC 2018). Climate change is strongly changing ecological conditions, influencing the growth conditions of tree species; therefore, it is a challenge for forest management planning because not all experiences from the past decades or the last centuries are useful under the new conditions.

Nevertheless, direct relations from changes in temperature or precipitation into changes in ecological characteristics of tree species, such as increments in diameter at breast height $(d b h)$, regeneration frequency, and mortality rate are not easily possible, but their correlated trends can be shown, e.g., by Bošel'a et al. (2019).
Learning from the past, it is possible to identify trends and extrapolate these trends to the future. This process is not directly possible as climate change is not a linear but a fluctuating process. In addition to climate change, other changing aspects such as management, air pollution loads, or game browsing are influencing tree health and growth (Bošel'a et al. 2019).

In addition to the direct impact of climate change on the growth and productivity of tree species, climate change also increases the frequency and intensity of natural disturbances (Seidl et al. 2014). In the forests on the Western Carpathian Mountains, disturbances occur mainly in old even-aged spruce forests (Hlásny et al. 2017). Uneven-aged mixed forests are more stable under climate change (Griess et al. 2012; Roessiger et al. 2013). Nevertheless, yield tables often underestimate growth and are only suitable for even-aged single species

*Corresponding author.Gerhard Rößiger, e-mail: rossiger@nlcsk.org 
management planning (Pretzsch et al. 2014). Solutions for forest management planning are growth simulators such as the matrix transition model (e.g., Usher 1969), which also includes density-dependence (Buongiorno \& Michie 1980). The matrix transition model is a simulator to predict population dynamics (Lewis 1942; Leslie 1945). Applied to uneven-aged forestry, the model is able to implement actual inventory data structured into $d b h$ classes (Buongiorno \& Michie 1980) rather than age. Matrix transition models typically consist of ecological models such as 1) transition probabilities to the next higher $d b h$ class, 2) ingrowth frequencies in the lowest $d b h$ class, and 3) mortality probabilities by $d b h$ classes to predict overall stand development.

Liang et al. (2011) applied matrix modelling to estimate expected forest dynamics under climate change, e.g., regarding changes in species composition in the Alaska coastal forest, which is sensitive to site productivity, plot elevation, plot aspects, and total stand basal area $(b a)$, but also the mean temperature and precipitation during the growing season.

Growth trends of species under climate change are also evident in the regional findings of Bosela et al. (2019). To consider such growth trends in management planning tools, they were implemented into the matrix transition model of Roessiger et al. (2018). By using a harvest optimiser included in the simulation, a goal towards optimal forest management can be determined. Aplanning goal is an equilibrium defined as a hypothetical long-term stable species and diameter distribution under assumed stable conditions to achieve the highest continuous financial yield. The purpose is to estimate the sensitivity of this equilibrium under the changing climate. The intention is to confirm the hypothesis: equilibrium states of $b a$, species composition, $d b h$ distribution, and target harvest $d b h$ in the mixed uneven-aged forest fluctuate and are sensitive to changes in ecological growth conditions over time.

\section{Material and methods}

\subsection{Study area}

The study area represents the "Pro Silva" model forest unit Smolnícka Osada covering 2,132 hectares of forest in the Volovské Mountains in the Central West Carpathians ( $48^{\circ} 44^{\prime} \mathrm{N}, 20^{\circ} 46^{\prime} \mathrm{E}$ ). The altitude ranges from 440 to $1,150 \mathrm{~m}$ above sea level, the geological bedrock is formed mainly by phyllites with a dominant representation of dystric and typical cambisols (Kulla et al. 2017). The territory was affected by acid air pollution from remote sources combined with local pollution from metal processing industries, which culminated in the 1980s and decreased significantly in the 1990s. Mixed, continuouscover, single-tree to group selective forestry, so-called plenter forest management, was established since 1950 in the mixed beech-fir-spruce forests with admixed pine, resulting in uneven-aged forest structures with spontaneous natural regeneration of beech, spruce and fir. Particularly, fir regeneration has been increasingly damaged by the continually rising population of ungulate game since the 1960s.

The region is structured in three strata: stratum A is the biggest and represents the upper altitudinal belt dominated by beech and fir with spruce admixture; stratum B is situated in the lower altitudinal belt dominated by spruce and older pines with fir and beech admixture, which was influenced by pasturing in the past centuries; and stratum X represents smaller protective forests on exposed sites spread over the total study region with various species composition (Kulla et al. 2018).

\subsection{Growth history}

Using tree-ring methods, Bosela et al. (2019) evaluated the effects of changed environmental conditions in the model forest unit on long-term changes in radial increments during a period from 1900 - 2014. Input for this study was tree-ring samples from 319 beeches, 283 firs, 111 spruces, and 64 pines from Smolnícka Osada in 2014. The measured tree ring widths were transformed into basal area increments of a single tree (bai). Conversion of tree-ring width into bai removes biases of productivity estimates (Bouriaud et al. 2015). Further, bai better correlates to the volume added to circular stems than tree ring width (Biondi \& Qedan 2008).

A generalised additive mixed model was used to compare bai of four species in mixture and altitudinal (lower than and higher than $800 \mathrm{~m}$ a.s.l) categories. A linear mixed-effect model was used to estimate the effects of $d b h$, temperature, precipitation, and crown characteristics on bai variation and to test the effects of climate, competition and species diversity on bai variation (Bosela et al. 2019).

The species-specific forest growth history was typified as follows:

- high spruce increment at the beginning of the $20^{\text {th }}$ century followed by a strong decline of spruce during the last decades,

- relatively stable beech increment with a slight increase and some fluctuation,

- an apparent minimum of fir increment in 1980 caused by the emission load of heavy metals such as mercury, lead, and arsenic elements, followed by a substantial recovery of fir due to both the warmer climate and reduced air pollution,

- a moderate decline of the pine increment since the middle of the last century.

\subsection{Matrix transition model}

The matrix model of Roessiger et al. (2018) was based on an inventory of the model forest unit in the year 2014 
on 344 inventory plots. Typically, regression of transition, ingrowth, and mortality requires two inventories to estimate the differences within a period. Therefore, an inventory was recalculated for the year 2004 by Kulla et al. (2017). This inventory serves as a reference.

Each step to simulate a new stand structure is ten years. The $d b h$ - class width is $4 \mathrm{~cm}$, and the model comprises $d b h$ classes with class means from 10 to $98 \mathrm{~cm}$.

The typical matrix model (Buongiorno \& Michie 1980 ) is extended to specify the ideas of modelling by Roessiger et al. (2016, 2018): individual sub-models consider tree species of beech, fir, spruce, and pine; crown characteristics (section 2.5.1); as well as stem characteristics (section 2.6).

The matrix model was applied individually for four case studies in example years 1910, 1950, 1980, and 2014, each representing a historical phase of stand development. The matrix model was used for simulation and detection of an optimal equilibrium state that is sensitive to growth conditions typical for the preselected example years in the growth history. The matrix model was based on or adapted from Roessiger et al. (2018) and Kulla et al. (2018). Matrix modelling was adapted stepwise to demonstrate the effects of single changes of inputs in four studies. In the first step, only the transition probabilities (T, section 2.5.1) were adapted, with further ingrowth (I, section 2.5.2) and then mortality (M, section 2.5.3), concluded by a case study on ingrowth reduction by game browsing $(G, 2.5 .4)$. A financial evaluation (section 2.6) allowed financial optimisation of the harvest (section 2.7).

\subsection{Modelling of historical increments and historical inventory data}

The matrix model requires a $d b h$ scale. Therefore, it was necessary to again retransfer the final value of bai for an example year by Bošel'a et al. (2019) to the unit of the $d b h$ increment.
The coefficient $I_{m, y} / I_{m, 2014}$ represents the mean $(m)$ of the $d b h$ increment $I_{m, y}$ (Table 1$)$ for a species in an example year $(y)$ relative to the reference year $2014 I_{m, 2014}{ }^{*}$

In the original inventory dataset, the decennial $d b h$ increment $I_{n, 2014}$ between years 2004 and 2014 for each single tree $n$ was multiplied by the coefficient $I_{m, y} / I_{m, 2014}$ for a specific example year to derive an individual $d b h$ increment of $I_{n, y}$ for this tree. This modelling ensures that the proportions between single trees remain the same independently of the example year.

$$
I_{n, y}=I_{n, 2014} * I_{m, y} / I_{m, 2014} ; y=1910 ; 1950 ; 1980 ; 2014
$$

Each single tree $d b h$ from the first year of inventory (2004) was added with the adapted increment $I_{n, y}$ to calculate the hypothetical individual $d b h$ in the second year. In this way, the specific virtual inventory data set prepared for matrix modelling was obtained for each example year. This modelling indicates a simplification, but the real $b a$ and initial stand state composition were unknown for the historical states.

\subsection{Matrix sub-models adapted by the historical change in increment}

\subsubsection{Transition adapted by the historical change in increment}

The transition (study T) describes the change for a tree from the current to a higher $d b h$ class within ten years and is estimated as probability. Typically, the transition occurs to the next $d b h$ class, and the remaining proportion stays in the same $d b h$ class. Roessiger et al. (2018) allowed trees with long crowns to transition to the next or next-but-one $d b h$ class due to their correlation with improved growth. For this purpose, two classes for a crown proportion length longer and shorter than $2 / 3$ of the tree height were distinguished and consistently applied to each tree species except pine, which had only short crowns. Although the transition to the next-but-one

Table 1. Increment data published by Bosela et al. (2019) related to strata in the model territory by Kulla et al. (2018), and the derived coefficient $I_{m, y}$ and $I_{m, y} / I_{m, 2014}$ used for model adaptation.

\begin{tabular}{|c|c|c|c|c|c|}
\hline Altitude and respective stratum & Tree species & Example year & $\begin{array}{c}\text { Basal area increment bai } \\
{\left[\mathrm{cm}^{2} \text { year }^{-1}\right]}\end{array}$ & $\begin{array}{l}\text { Diameter increment } I_{m, y} \\
{\left[\mathrm{~cm} \text { year }^{-1}\right]}\end{array}$ & $\begin{array}{c}I_{m, y} / I_{m, 2014} \\
\text { increment relative to year } 2014\end{array}$ \\
\hline \multirow{12}{*}{$\begin{array}{l}\text { Higher than } \\
800 \mathrm{~m} \\
\text { (stratum A) }\end{array}$} & \multirow{4}{*}{ Beech } & 1910 & 10 & 3.568 & 0.79 \\
\hline & & 1950 & 13 & 4.068 & 0.90 \\
\hline & & 1980 & 13 & 4.068 & 0.90 \\
\hline & & 2014 & 16 & 4.514 & 1.00 \\
\hline & \multirow{4}{*}{ Fir } & 1910 & 15 & 4.370 & 0.89 \\
\hline & & 1950 & 13 & 4.068 & 0.83 \\
\hline & & 1980 & 7 & 2.985 & 0.61 \\
\hline & & 2014 & 19 & 4.918 & 1.00 \\
\hline & \multirow{4}{*}{ Spruce } & 1910 & 45 & 7.569 & 2.54 \\
\hline & & 1950 & 33 & 6.482 & 2.17 \\
\hline & & 1980 & 19 & 4.918 & 1.65 \\
\hline & & 2014 & 7 & 2.985 & 1.00 \\
\hline \multirow{4}{*}{$\begin{array}{l}\text { Lower than } \\
800 \mathrm{~m} \\
\text { (stratum B) }\end{array}$} & \multirow{4}{*}{ Pine } & 1910 & 13 & 4.068 & 1.20 \\
\hline & & 1950 & 12 & 3.909 & 1.15 \\
\hline & & 1980 & 11 & 3.742 & 1.11 \\
\hline & & 2014 & 9 & 3.385 & 1.00 \\
\hline
\end{tabular}


$d b h$ class is a violation of the Usher assumption (Usher 1969), it had already been applied by Solomon et al. (1986) and Roessiger et al. (2016, 2018).

Based on the adapted dataset (Kulla et al. 2018), a binary logistic regression was applied because of the benefit of allowing only transition probabilities between 0 and 1. Regression was carried out for generalised linear models via the R function "glm" (R Core Team 2015). The transition probability depended on $d b h$ and $b a$, except for spruce, which only depended on ba (Table 2).

$$
p=1 /\left(1+\exp \left(-\left(c_{0}+c_{1} * d b h+c_{2} * b a\right)\right)\right)
$$

\subsubsection{Expected ingrowth positively correlated to increment}

Adaptation of historical transition was based on the measurements of Bosela et al. (2019), but transition alone cannot represent the complete change in species characteristics over time. Ingrowth frequency represents the number of trees passing the $d b h$ of $8 \mathrm{~cm}$ within ten years. Because of the unknown ingrowth in the past, the assumption was accepted that $d b h$ increments indicate the general health state of the species and that ingrowth is positively correlated with the $d b h$ increment. The Weibull (2-parameter) probability density function for ingrowth (ING) of Roessiger et al. (2018) for data of all stratum was multiplied by the coefficient $I_{m, y}$ of the stratum higher than $800 \mathrm{~m}$ (Table 1) to derive study (I). The coefficients are the scale parameter $\lambda$, the shape parameter $k$ (fixed to value 2), and a calibration parameter $c$ to adapt the $\mathrm{x}$-axis to represent higher $b a$ values. Regression was carried out with the "nls" function (an R package "minpack.
Im" based on a nonlinear least-squares algorithm) in R software (R Core Team 2015). Coefficients for $\lambda$ were $0.0277,0.0728,0.0324$, and for $c 1094,508,445$, for beech, fir and spruce, respectively.

$$
I N G=\frac{\kappa}{\lambda}\left(\frac{b a / c}{\lambda}\right)^{\kappa-1} * \exp ^{-\left(\frac{b a / c}{\lambda}\right)^{\kappa}} * I_{m, y}
$$

Only ingrowth from plots with at least one seed tree of more than $40 \mathrm{~cm}$ was considered in the regression. As a result, ingrowth was low for a $b a$ of 0 and for a very high $b a$, with the maximum observed for a species-specific optimal $b a$. Optimal $b a$ was highest for shade-tolerant fir with $26 \mathrm{~m}^{\wedge} 2$ /ha and beech with $21 \mathrm{~m}^{\wedge} 2$ /ha and lowest for spruce with $10 \mathrm{~m}^{\wedge} 2 /$ ha. Pine ingrowth was set to 0 as it had no sufficient ingrowth under the canopy of shade-tolerant species during succession.

A binary logistic regression (as used for transition) that was sensitive only to ba separated ingrowth into crown classes. In the case of low $b a$, a higher proportion had a long crown. The regression coefficients for the Intercept were $0.82,1.39,-0.544$ and for $b a-0.0058$, $-0.0352,-0.0111$ for beech, fir, and spruce, respectively.

\subsubsection{Expected mortality negatively correlated to increment}

Similar to transition, adaptation of the mortality (study M) data for reference inventory was applied based on observed increment dynamics. Mortality is the probability of trees naturally dying every ten years. Single tree mortality is assumed to negatively correlate with the health state and $d b h$ increment in the past.

Table 2. Coefficients of the binary logistic regression of transition probability and their statistics (database described in section

\begin{tabular}{|c|c|c|c|c|c|c|c|c|c|}
\hline \multirow{2}{*}{$\begin{array}{l}\text { Species } \\
\text { crown } \\
\text { class }\end{array}$} & \multirow[b]{2}{*}{ Coefficient } & \multicolumn{2}{|c|}{1910} & \multicolumn{2}{|c|}{1950} & \multicolumn{2}{|c|}{1980} & \multicolumn{2}{|c|}{2014} \\
\hline & & Estimate & $\begin{array}{l}\text { Sign. } \\
\text { Level }\end{array}$ & Estimate & $\begin{array}{l}\text { Sign. } \\
\text { Level }\end{array}$ & Estimate & $\begin{array}{l}\text { Sign. } \\
\text { Level }\end{array}$ & Estimate & $\begin{array}{l}\text { Sign. } \\
\text { Level }\end{array}$ \\
\hline Beech & Intercept & 0.792 & ** & 1.233 & $* * *$ & 1.233 & $* * *$ & 2.3 & $* * *$ \\
\hline short & $d b h$ & 0.0409 & $* * *$ & 0.0594 & $* * *$ & 0.0594 & $* * *$ & 0.0708 & $* * *$ \\
\hline crown & ba & -0.021 & * & -0.0325 & $* * *$ & -0.0325 & $* * *$ & -0.0532 & $* * *$ \\
\hline Beech & Intercept & -1.971 & $* * *$ & -1.42 & $* * *$ & -1.42 & $* * *$ & -1.06 & $* * *$ \\
\hline long & $d b h$ & 0.0499 & $* * *$ & 0.0424 & $* * *$ & 0.0424 & $* * *$ & 0.0433 & $* * *$ \\
\hline crown & $b a$ & -0.128 & $* * *$ & -0.0926 & $* * *$ & -0.0926 & $* * *$ & -0.0747 & $* * *$ \\
\hline Fir & Intercept & -0.0002 & & -0.216 & & -0.903 & $* * *$ & 0.75 & * \\
\hline short & $d b h$ & 0.0572 & ** * & 0.0507 & $* * *$ & 0.0458 & $* * *$ & 0.0653 & $* * *$ \\
\hline crown & $b a$ & -0.0222 & ** & -0.0166 & * & -0.0133 & * & -0.0347 & $* * *$ \\
\hline Fir & Intercept & -0.818 & $* *$ & -0.942 & $* * *$ & -0.588 & 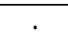 & -0.455 & . \\
\hline long & $d b h$ & 0.0615 & $* * *$ & 0.0594 & $* * *$ & 0.0414 & $* * *$ & 0.0616 & $* * *$ \\
\hline crown & $b a$ & -0.0341 & $* * *$ & -0.0372 & $* * *$ & -0.0739 & $* * *$ & -0.0304 & $* * *$ \\
\hline & Intercept & 1.108 & * & 1.145 & * & 1.104 & * & 0.927 & . \\
\hline Pine & $d b h$ & 0.026 & * & 0.0209 & . & 0.0191 & . & 0.0182 & . \\
\hline & ba & -0.0226 & * & -0.021 & . & -0.0209 & . & -0.0198 & . \\
\hline Spruce & Intercept & 3.7 & $* * *$ & 3.022 & $* * *$ & 2.202 & $* * *$ & 0.8652 & * \\
\hline crown & $b a$ & -0.064 & $* * *$ & -0.0711 & $* * *$ & -0.0673 & $* * *$ & -0.0505 & $* * *$ \\
\hline Spruce & Intercept & 5.447 & $* * *$ & 4.554 & $* * *$ & 3.562 & $* * *$ & 0.1784 & \\
\hline $\begin{array}{l}\text { long } \\
\text { crown }\end{array}$ & $b a$ & -0.191 & $* * *$ & -0.178 & $* * *$ & -0.176 & $* * *$ & -0.1063 & $* *$ \\
\hline
\end{tabular}
2.4).

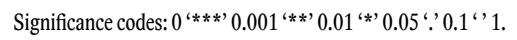


Original mortality probabilities $M_{-} p_{n, y}$ (with $n$ as the single salvage proportions derived from forest stand management records of all strata) specific for species and the mean $d b h$ of a stand layer were divided by the coefficient $I_{m y}$. The only restriction was a maximum salvage proportion of $100 \%$, but it was relevant to adaptation only for 5 of the 673 cases of fir. The other species did not need the correction.

$$
\begin{gathered}
M \_p_{n, y}=M \_p_{n, 2014} / I_{m, y} ; \\
O \leq M_{-} p_{n, y} \leq 1
\end{gathered}
$$

Using the adapted mortality data from all strata, a binary logistic regression utilising the "glm" function in R (R Core Team 2015) was applied to estimate the probability of mortality dependent on $d b h$ (Table 3 ).

$$
p=1 /\left(1+\exp \left(-\left(c_{0}+c_{1} * d b h\right)\right)\right)
$$

\subsubsection{Case study of reduced ingrowth due to increased game browsing}

To consider the increased game density and browsing in the last decades starting in the 1960s, the observed ingrowth of fir in study I was increased by $100 \%$ (doubled) for year 1910 and 1950 , by $50 \%$ for year 1980 and remained as observed for year 2014 for study G.

\subsection{Financial evaluation}

The financial value of a tree is considered a net cash flow $(N C F)$ per tree stem. $N C F$ is calculated as the net timber price related to the timber volume per stem (Petráš \& Pajtík 1991). The net timber price is the timber price based on tree assortment tables that are sensitive to species, stem quality, and stem damage, as reported by Petráš et al. (2017), minus harvest costs including 8.92 $€ /$ hour related to time using standards (Ministry for Forest and Water Management of the Slovak Republic, 1992a, 1992b), actual hour rates and chain saw compensation, plus $2.15 € \mathrm{~m}^{-3}$ tractor compensation.

Further sub-division within each species are the individual $N C F$ for two classes distinguished by good and bad stem quality considering also stem damage. Ingrowth was allocated to the stem classes by fixed proportions observed by the reference inventory. Good stems were $34 \%$ of beech, $58 \%$ of fir, $41 \%$ of spruce, and $71 \%$ of pine.

The resulting net timber prices per stem were $10-$ $14 €$ for a $d b h$ of $10 \mathrm{~cm}, 80-140 €$ for a $d b h$ of $42 \mathrm{~cm}$, and $250-350 €$ for a $d b h$ of $66 \mathrm{~cm}$. Prices were lower for bad stems and higher for spruce and fir compared with pine and beech.

In the case of mortality, only $75 \%$ of $N C F$ was considered in the financial evaluation.

A simulation step $t$ was ten years, within a total simulation period $T$ of 400 years. The harvest cycle was 20 years. A single $N C F$ was calculated separately for each possible combination of each individual species, crown, stem, and $d b h$ class $c$ of all combinations of these classes $C$ for a given $t$. $N C F$ was calculated for standing tree $N C F$ s, for trees failed by mortality $N C F m$, and for trees harvested $N C F h$. Mortal timber dying over a period of two decades (NCFm1 and NCFm2) was summarised and was harvested together with the following planned harvest.

A concept to evaluate total financial stand performance over time is the net present value (NPV). NPV was adjusted by holding value (Deegen et al. 2000), which was already used by Roessiger et al. (2016 and 2018). This type of $N P V$ considers the financial value of the remaining stand at the beginning and end to ensure that no clearcut was ultimately conducted. Each single NCF was discounted by an interest rate $i$ of $2 \%$.

$$
\begin{aligned}
& N P V_{c, T=400}=\sum_{c}^{c}\left(-N C F s_{c, t=0}+\sum_{t=0}^{T-20}\left(\frac{N C F h_{c, t}}{(1+i)^{t}}+\right.\right. \\
& \left.\left.+\frac{N C F m 1_{c, t}}{(1+i)^{t+20}}+\frac{N C F m 2_{c, t+10}}{(1+i)^{t+20}}\right)+\frac{N C F s_{c, T}}{(1+i)^{T}}\right)
\end{aligned}
$$

\subsection{Financial optimisation}

The optimisation objective to estimate the optimal harvest strategy was a maximisation of $N P V$. Optimisation means to test the harvest by testing all combinations $C$ in all periods $t$ simultaneously and to choose only the combination that results in the maximum $N P V$. Harvest optimisation was carried out within the simulation framework

\begin{tabular}{|c|c|c|c|c|c|c|c|c|c|}
\hline \multirow[b]{2}{*}{ Species } & \multirow[b]{2}{*}{ Coefficient } & \multicolumn{2}{|c|}{1910} & \multicolumn{2}{|c|}{1950} & \multicolumn{2}{|c|}{1980} & \multicolumn{2}{|c|}{2014} \\
\hline & & Estimate & $\begin{array}{l}\text { Sign. } \\
\text { Level }\end{array}$ & Estimate & $\begin{array}{l}\text { Sign. } \\
\text { Level }\end{array}$ & Estimate & $\begin{array}{l}\text { Sign. } \\
\text { Level }\end{array}$ & Estimate & $\begin{array}{l}\text { Sign. } \\
\text { Level }\end{array}$ \\
\hline & Intercept & -6.966 & $* * *$ & -7.097 & $* * *$ & -7.097 & $* * *$ & -7.2 & $* * *$ \\
\hline Beech & $d b h$ & 0.0645 & * & 0.0645 & 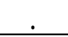 & 0.0645 & . & 0.0644 & \\
\hline & Intercept & -4.429 & $* * *$ & -4.360 & $* * *$ & -4.069 & $* * *$ & -4.542 & $* * *$ \\
\hline FIr & $d b h$ & 0.0451 & * & 0.0452 & $* *$ & 0.0462 & $* *$ & 0.0448 & * \\
\hline Pine & $\begin{array}{l}\text { Intercept } \\
d b h\end{array}$ & $\begin{array}{l}-5.622 \\
0.0306\end{array}$ & . & $\begin{array}{l}-5.582 \\
0.0306\end{array}$ & . & $\begin{array}{l}-5.538 \\
0.0306\end{array}$ & . & $\begin{array}{l}-5.438 \\
0.0307\end{array}$ & . \\
\hline Spruce & $\begin{array}{l}\text { Intercept } \\
d b h\end{array}$ & $\begin{array}{l}-4.818 \\
0.0754\end{array}$ & $\begin{array}{l}* * * \\
* * *\end{array}$ & $\begin{array}{l}-4.673 \\
0.0763\end{array}$ & $\begin{array}{l}* * * \\
* * *\end{array}$ & $\begin{array}{l}-4.421 \\
0.0785\end{array}$ & $\begin{array}{l}* * * \\
* * *\end{array}$ & $\begin{array}{l}-3.996 \\
0.0849\end{array}$ & $\begin{array}{l}* * * \\
* * *\end{array}$ \\
\hline
\end{tabular}
by using the Subplex algorithm of Rowan (1990) implemented into the R programme (R Core Team 2015) by King (2015).

Table 3. Coefficients of binary logistic regression of mortality probability and their statistics, (database described in section 2.4).

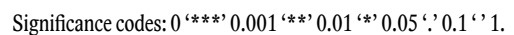


The Subplex algorithm requires technical constraint by harvesting only a proportion between $0 \%$ and $100 \%$ of existing trees in each $d b h$ class before each simulation step. This constraint is achieved by an "If " function entry with a high negative value in the case of harvesting more trees than exist or a negative number of trees. Subplex minimises the goal function, therefore minimising a technically negative $N P V$.

Only the equilibrium in year 240 before the harvest was used for results to represent typical stable mean conditions excluding two types of fluctuations that typically occur during the optimisation cycle. 1 . At the beginning of the optimisation, the species and diameter distribution changed from the known initial state in 2004 to the optimal state. 2. At the end of the optimisation, ba increased, caused by the lack of necessity for future investment in ingrowth (Roessiger et al. 2018).

\section{Results}

The results are presented as a comparison of the optimised management equilibrium characterised by $b a$, harvest, $d b h$ distribution and target $d b h$ by species for the four different cases described above (T, I, M, G) and for different times represented by four example years (1910, 1950, 1980, 2014).

The cases are defined as additional, according to the extent of adaptations regarded in the matrix modelling: R - reference study of year 2014 based only on observed data without adaptations,

$\mathrm{T}$ - includes R and only adapted transition probabilities related to historical increment data,

I - includes R, T plus adapted ingrowth

frequencies correlated positively to diameter growth, M - includes R, T, I, plus adapted mortality rates correlated negatively to diameter growth,

G - includes R, T, I, M, plus consideration of reduced game browsing of fir in the past.

For year 2014, R is identical to T, I, M, and G and, therefore, only presented once. Essential results concerning optimal $b a$ and optimal harvest including financial value are presented for all cases. Detailed results for diameter distribution and target diameters are provided as examples for case $T$ as the most methodologically clean case supported by historical data, and for case $\mathrm{G}$, which, even if based on more assumptions, is hypothetically the most realistic.

\subsection{Differences in optimal stand basal area, mortality and financial value of the harvest}

Comparing the four studies for the exampleyears regarding the remaining stand indicates in terms of the species ecology, a lower ba was related to a higher spruce proportion, while a higher ba was related to higher beech and mainly higher fir proportions. Modelling of the light- demanding spruce showed the most intensively positive reaction to changes, especially on I but also on $M$, as occurred at the beginning of the last century. The spruce decline during the evaluated time period was rapid, and a trend extrapolation would lead to complete spruce extinction in the study region in the future, as already projected for pine due to missing pine ingrowth.

In G1910, the ba of fir was two times higher compared with M 1910, although the fir target $d b h$ structure was the same. The cause was the lower browsing by game. Fir $b a$ declined until 1980 and then came back until 2014, which would have been more intensive if fir ingrowth had not been limited by recent game browsing. Beech became more dominant with each time step (Fig. 1).

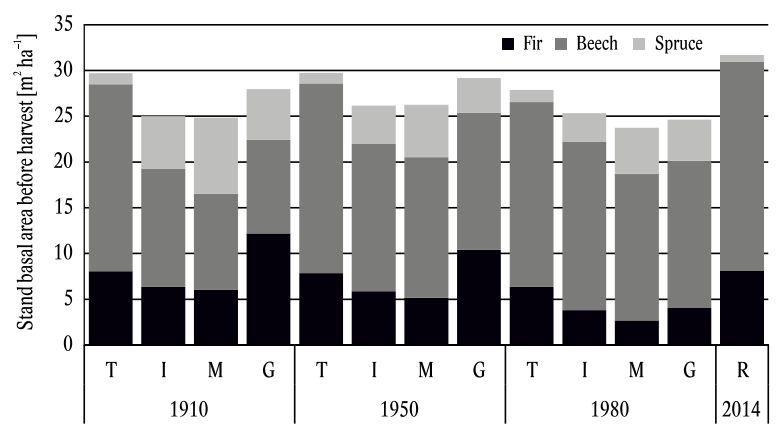

Fig. 1. Optimal stand basal area in the optimised equilibrium state before harvest for the different example years.

Ba summarising timber failed by mortality (Fig. 2) was strongly distinguished from the $b a$ standing. Although beech formed the majority of the ba proportion of $G$ since 1950, it had a relatively low mortality probability. In studies $\mathrm{T}$ and $\mathrm{G}$, fir had the highest proportion of mortality from $b a$ in all example years except 1980 . The reason for the high fir mortality was its high-value increment potential; therefore, the optimiser allowing fir to reach a high target $d b h$ (Fig. 4) correlated with the naturally increasing probability of mortality, although fir mortality rates, in fact, were significantly lower compared with those of spruce.

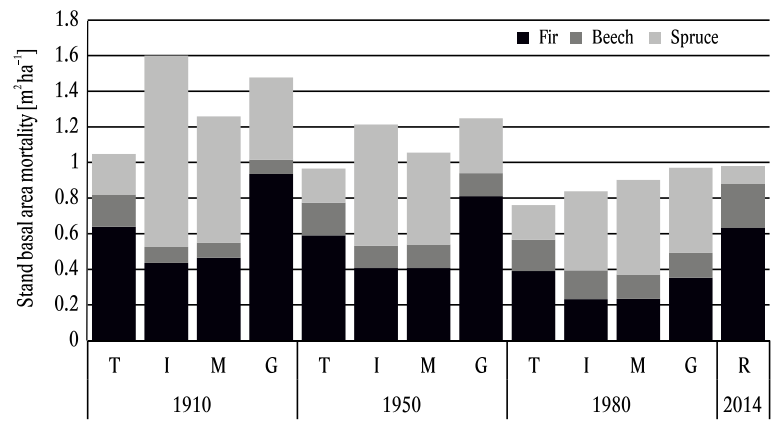

Fig. 2. Basal area of mortality in the optimised equilibrium state for a 20 -year harvest cycle for the different example years.

The financial value of the fir harvest was higher compared with the respective proportions of $b a$ because the net timber price of the fir harvest increased over-pro- 
portionally to the higher target $d b h$ (see also Fig. 6). For spruce characterised by a lower target $d b h$, the proportion of financial value was lower than the respective $b a$ proportion. For study $\mathrm{G}$ in 1910 , fir formed the main proportion of the financial value of the harvest (Fig. 3).

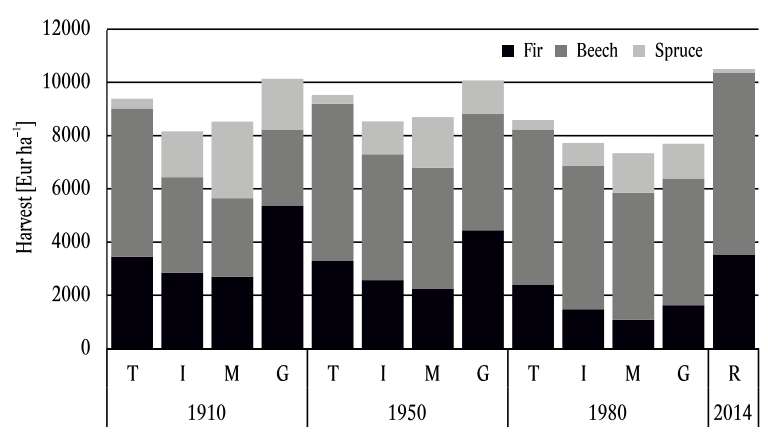

Fig. 3. Financial value of the optimal harvested part of the stand in the equilibrium state for a 20 -year harvest cycle.

\subsection{Differences in optimal diameter distribution}

In study T, conditions for spruce were best in the year 1910 , resulting in a relatively fast transition compared with the otheryears. In 1980, a large number of firs accumulated in the lower $d b h$ classes and did not transit to the next $d b h$ class because fir transition probability was low in comparison to other years due to culminating air pollution. In the year 2014, the $d b h$ distribution became flatter because the beech and fir trees in lower $d b h$ classes transited more rapidly to higher classes and the target $d b h$ was higher (Fig. 4).
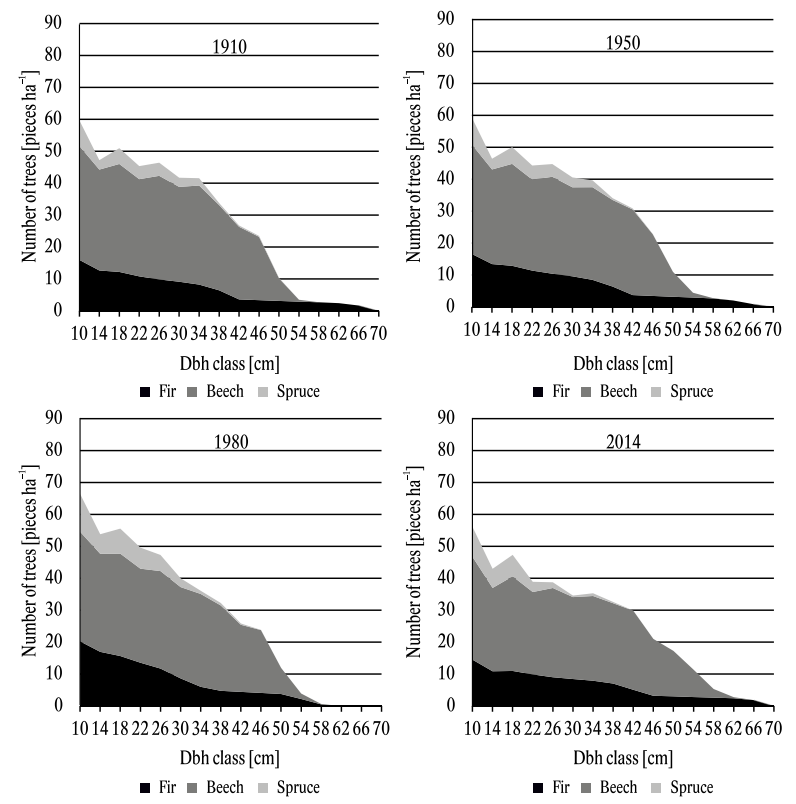

Fig. 4. Differences in optimal diameter distribution in equilibrium to study only the adaptation of transition probability supported by historical increment data.
For study G compared with T, the $d b h$ distribution of beech became steeper and excluded higher $d b h$ classes for earlier example years. Both changes were caused by lower ingrowth and higher mortality involved through regarded expectations about the correlation of these processes with increment dynamics. The same worse conditions as observed for beech at the beginning of the last century were experienced by fir, but fir was supported by double ingrowth thanks to the assumption about lowered game browsing in 1910 and 1950; otherwise it was comparable to beech.

The number of ingrowths by species entering the lowest $d b h$ class depended on the actual $b a$, actual ingrowth rates, and species shade tolerance in the order fir-beech - spruce. For the G case, beech ingrowth was nearly constant, spruce ingrowth profited in 1910 from spruce vitality and in 1980 from lowered $b a$ due to the fir decline, and fir ingrowth continuously decreased due to the increasing game browsing (Fig. 5).
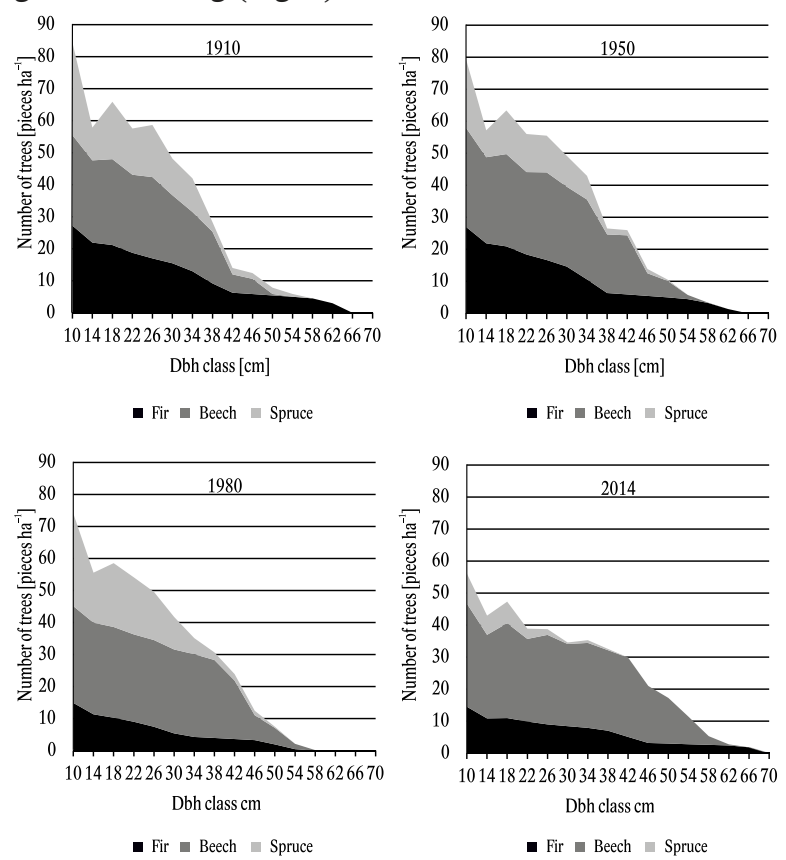

Fig. 5. Differences in optimal diameter distribution in equilibrium for the case applying all adaptations based on historical data and all sets of predefined expectations.

\subsection{Differences in target harvest diameter}

The change in target $d b h$ over time within one tree species depends especially on the change in transition probabilities determining the value increment, as well as mortality lowering timber price. For beech, from year 1910 up to 2014 , stability or an increase in target $d b h$ for all classes was achieved. The target $d b h$ of the fir classes was nearly constant in the years 1910,1950, and 2014. The year 1980 saw a reduction in all fir classes. The target $d b h$ of long crown firs reached up to $12 \mathrm{~cm}$ lower compared with 2014 . The spruce target $d b h$ declined continually from 1910 to 2014 (Fig. 6). 
When comparing study I to study T, some beech and fir classes in 1910 and 1950 showed a decreased target $d b h$ by $4 \mathrm{~cm}$. The driver decreasing the target $d b h$ before 1980 was the lower ecological potential of beech and fir to produce ingrowth. The optimiser decided for a lower $b a$ to support ingrowth to balance the lacking ingrowth before 1980. Due to the fir decline in 1980, the fir target $d b h$ and $b a$ were already lower compared with other years, and the low $b a$ did not depend on a decrease in the target $d b h$ of beech. Only spruce showed cases with an increased target $d b h$ by $4 \mathrm{~cm}$ in 1980 because the lightdemanding spruce benefited from the lower $b a$.

In study M compared with study I, further changes in target $d b h$ appeared. Some cases of target $d b h$ of fir and beech classes declined by $4 \mathrm{~cm}$ due to higher mortality in the earlier years. In the cases of spruce classes, target $d b h$ increased by $4 \mathrm{~cm}$ (Fig. 6). Nevertheless, the changes in target $d b h$ from I to $\mathrm{M}$ in combination did not change ba but changed proportions of $b a$. Spruce showed an increased proportion due to lower mortality, while fir showed decreased proportions due to higher mortality. The beech proportion remained constant in 1950 and 1980 and slightly declined in 1910 (Fig. 1).
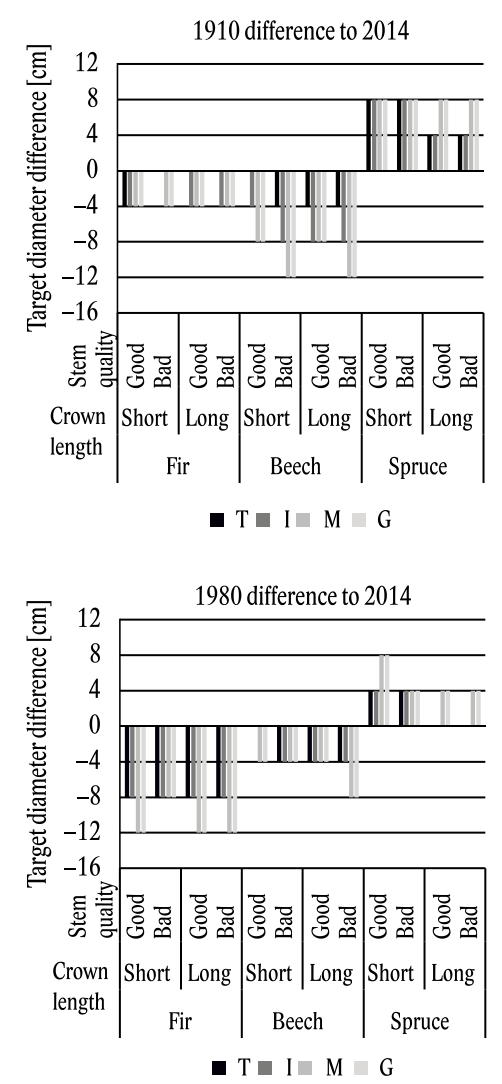

\section{Discussion}

\subsection{Not considering the effects of changed management and ecological succession}

The results revealed changing states of the optimal $d b h$ distribution and species composition of an optimised equilibrium resulting from changing growth conditions and, consequently, changing increments over time. The main reason for these changes in the region of interest might be climate, especially temperature, the carbon dioxide concentration in the atmosphere and the emission load of heavy metal (Bosela et al. 2019).

Pretzsch et al. (2014) found an increase in increment for beech and especially young spruce in Central Europe since 1870. Additionally, Šimůnek et al. (2019) showed positive relation of the beech increment to a higher temperature in Krkonoše National Park (North of Czech Republic). Vacek et al. (2019) demonstrated a strong decrease in spruce increment between 1978 and 1987 as result of the air pollution load of sulphur $\left(\mathrm{SO}_{2}\right)$ in Jizerské Hory Mountains (North of Czech Republic), followed by spruce recovery. While beech results for Smolnícka Osada are in accordance with the findings of Pretzsch et al. (2014), spruce, in contrast, showed a strong linear decline. Bosela et al. (2019) demonstrated the negative effect of increased temperature on the spruce increment. Hence, some additional locally specific factors including
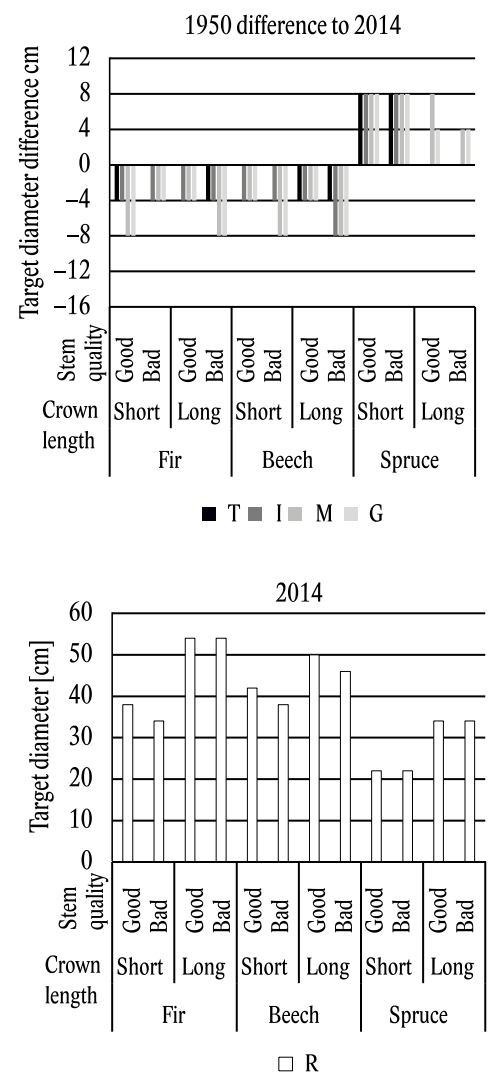

Fig. 6. Differences in target diameter in equilibrium with adaptations based on historical data and all sets of predefined expectations (crown classes: long, short; stem classes: good, bad). 
changed management might be a reason for the different trend of the spruce increment in the study of Smolnícka Osada.

Regardless, changed management is responsible for the continuous decline of pine. As a strongly lightdemanding species, pine benefited from the free land conditions and low ba in the past. A change to plenter forest management since 1950 supported shade-tolerant species and limited light-demanding species.

The ecological succession develops from the lightdemanding tree species pine over spruce to the shadetolerant species beech and fir. Spruce is currently disappearing, as the main species have become beech and fir. The process is still progressive in stratum B. Nevertheless, today there are strong differences between the ecological characteristics of stratum A characterised by high beech ingrowth and stratum $B$ characterised by high spruce ingrowth (Kulla et al. 2018).

The changed management, ecological succession, and their impacts on ecology could not be considered in Smolnícka Osada study because detailed data about the initial stand and true ecological models of ingrowth and mortality in the past are unknown and can only be assumed. Nevertheless, sensitivity studies of the ecological and management models are generally applied to identify the extent to which the matrix models react to changes, e.g., Ficko et al. $(2016,2018)$ applied management assumptions of no management, business-as-usual, profit maximisation, and maximisation of the number of firs in the smallest $d b h$ class to three Slovenian regions.

\subsection{Interpretation of simplified expectations to adapt ecological models}

Typically, the increment is an indicator of the health state and thus should indirectly positively correlate with ingrowth frequency and negatively correlate with the single tree mortality probability. The single tree mortality is a characteristic of close-to-nature and continuous-cover forestry and represents a different situation compared to stand-wise calamity. Calamity should partly positively correlate with increment due to the increased exposure to storm by the increased tree height or due to bark beetles by increased tree $d b h$, given the same stand age. Excluding on some small proportions of pure spruce stand, there is less calamity but more single tree mortality dominating in the study region.

Nevertheless, these correlations are assumptions, and the real ingrowth frequency and mortality probability during the evaluated historical time periods are unknown. Further, the historical initial stand state, timber prices and harvest costs are also unknown and are assumed to be constant and consistent with the current ones in the study of Smolnícka Osada.

Due to the unknown mortality and ingrowth, only study T, which adapted solely transition, represents a real estimated change. Studies I and M represent a frame of unknown but possible outputs rather than the expectation of the same values as in the year 2014. In addition, they allow testing of the sensitivity and limits of the advanced matrix modelling approach to search for the economically optimal equilibrium for uneven-aged forest management.

Study G might represent a case study concerning how a sufficient hunting regime might influence management, especially via improved conditions for fir. Our results signify that if the increasing negative influence of game on fir ingrowth tested in study $\mathrm{G}$ would not exist, the $b a$ as well as the financial value of forest would be higher than actually observed. Research on optimising $b a$ to improve fir ingrowth in three Slovenian regions resulted in an increase in the number of firs in small $d b h$ classes, but it was not sufficient in the case of high game pressure, as reported by Ficko et al. (2016).

\section{Conclusion}

The results of this study confirm that the optimal equilibrium of the uneven-aged forest can fluctuate over time as a consequence of changing environmental conditions. This study mainly shows trends of tree species development, which can be extrapolated to support planning for possible climatic conditions that are expected to appear in the future in the study region. Trusting tree species that are unsuitable under climate change might lead to a degradation of forests. Climate change forces the longterm adaptation of management. An adaptive management policy might even require the use and intermixing of native and non-native tree species (Bolte et al. 2009).

The optimality of equilibrium states reached by means of optimisation can only be a "temporal pseudogoal state" that varies over time. Consequently, it should be interpreted more as a direction of development of forest management than as a goal that must be immediately reached. This goal should be updated within regular planning intervals, typically when new inventory data are available. Such updates can be part of adaptive forest management related to "learning by doing" in the sense of Gadow (2006).

To allow options to adapt, management-sufficient possibilities must be available.

Nevertheless, the case of the rapid short-term fir decline around the year 1980 and its revitalisation demonstrates that some trends are reversible. A simple extrapolation of this temporal trend and its implementation into management planning would have led to the loss of fir in the study region. Therefore, especially for management relying on natural regeneration, changes in forest composition that are too fundamental and rapid can lead to an almost irreversible loss of a tree species that might be beneficial for until now not known future conditions. 
Further, it is beneficial to maintain a high species diversity even when some tree species are under pressure during the phases of forest development. Mixed, unevenaged, close-to-nature, and plenter management are the best options to prepare for future uncertainty by allowing small and continuous changes in species composition using natural regeneration. Flexible management must always adapt to temporal changes but may not completely trust in temporal trends, while retaining the fundamental criteria for sustainability.

\section{Acknowledgements}

This work was supported by the Slovak Research and Development Agency (Projects APVV-18-0195 SilvaMod andAPVV-150265 DENDROCLIM: 80\%); and by the Ministry of Agriculture and Rural Development of the Slovak Republic (Item No. 08V0301-Project SLOVLES: 20\%).

\section{References}

Biondi, F., Qeadan, F., 2008: A theory-driven approach to tree-ring standardization: Defining the biological trend from expected basal area increment. Tree-Ring Research, 64:81-96.

Bolte, A., Ammer, C., Löf, M., Madsen, P., Nabuurs, G. J., Schall, P. et al., 2009: Adaptive forest management in central Europe: Climate change impacts, strategies and integrative concept. Scandinavian Journal of Forest Research, 24:473-482.

Bošela, M., Kulla, L. Roessiger, J., Šebeň, V., Dobor, L., Büntgen, U., Lukac, M., 2019: Long-term effects of environmental change and species diversity on tree radial growth in a mixed European forest. Forest Ecology and Management, 446:293-303.

Bouriaud, O., Bréda, N., Dupouey, J. L., Granier, A., 2005: Is ring width a reliable proxy for stem-biomass increment? A case study in European beech. Canadian Journal of Forest Research, 35:2920-2933.

Buongiorno, J., Michie, B. R., 1980: A matrix model of uneven-aged forest management. Forest Science, 26:609-625.

Deegen, P., Villa, W., Stümer, W., Pretzsch, H., 2000: Zur finanziellen Analyse der Waldpflegeentscheidung bei Berücksichtigung der Biodiversität, dargestellt am Beispiel der Fichte in Sachsen. Forstwissenschaftliches Centralblatt, 119:226-244.

Ficko, A., Roessiger, J., Bončina, A., 2016: Can the use of continuous cover forestry alone maintain silver fir (Abies alba Mill.) in central European mountain forests? Forestry (London), 89:412-421.

Ficko, A., Roessiger, J., Bončina, A., 2018: Optimizing silviculture in mixed unevenaged forests to increase the recruitment of browse-sensitive tree species without intervening in ungulate population. iForest, 11:227-236.
Gadow, K. V., 2006: Forsteinrichtung: Adaptive Steuerung und Mehrpfadprinzip. Universitätsverlag Göttingen, 163 p.

Griess, V. C., Acevedo, R., Härtl, F., Staupendahl, K., Knoke, T., 2012: Does mixing tree species enhance stand resistance against natural hazards? A case study for spruce. Forest Ecology and Management, 267:284-296.

Hlásny, T., Barka, I., Roessiger, J., Kulla, L., Trombik, J., Sarvašová, Z. et al., 2017: Conversion of Norway spruce forests in the face of climate change: a case study in Central Europe. European Journal of Forest Research, 136:1013-1028.

Masson-Delmotte, V., Zhai, P., Pörtner, H. O., Roberts, D., Skea, J., Shukla, P. R. et al. (eds.), 2018: IPCC: Global Warming of $1.5^{\circ} \mathrm{C}$. An IPCC Special Report on the impacts of global warming of $1.5^{\circ} \mathrm{C}$ above pre-industrial levels and related global greenhouse gas emission pathways, in the context of strengthening the global response to the threat of climate change, sustainable development, and efforts to eradicate poverty.

King, A. A., 2015: Subplex: Unconstrained Optimization Using the Subplex Algorithm. R Package, Version 1.1-6.

Kulla, L., Bošela, M., Murgaš, V., Roessiger, J., Šebeň, V., 2017: Reconstruction of past forest status using inventory and tree ring data to support uneven-aged forest management. Central European Forestry Journal, 63:203-211.

Kulla, L., Roessiger, J., Sedliak, M., Murgaš, V., Šebeň, V., Sačkov, I., 2018: Inovatívne metódy tažbovej úpravy prírode blízkych lesov - koncept lesa hrúbkových tried. Lesnícke štúdie 66, Zvolen, NLC, p.

Leslie, P.H., 1945: The use of matrices in certain population mathematics. Biometrika, 33:183-212.

Lewis, E. G., 1942: On the generation and growth of a population. Sankhya Indian Journal of Statistics, 6:93-96.

Liang, J., Zhou, M., Verbyla, D. L., Zhang, L., Springsteen, A. L., Malone, T., 2011: Mapping forest dynamics under climate change: A matrix model. Forest Ecology and Management, 262:2250-2262.

Ministerstvo lesného a vodného hospodárstva Slovenskej republiky, 1992a:Výkonové normy pre sústred'ovanie dreva univerzálnymi, pásovými a špeciálnymi lesnými kolesovými traktormi, Zborník 24.

Ministerstvo lesného a vodného hospodárstva Slovenskej republiky 1992b: Výkonové normy pre tažbu dreva, Zborník 21.

Petráš, R., Pajtík, J., 1991: Sústava česko-slovenských objemových tabuliek drevín. Lesnícky časopis, 37:49-56.

Petráš, R., Mecko, J., Kulla, L., 2017: Economic value production of trees as a criterion of their maturity in an uneven-aged forest. Central European Forestry Journal, 63:188-194. 
Pretzsch, H., Biber, P, Schütze, G., Uhl, E., Rötzer, T., 2014: Forest stand growth dynamics in Central Europe have accelerated since 1870 . Nature Communications, 5:4967.

R Core Team, 2015: R: Language and Environment for Statistical Computing. R foundation for Statistical Computing, Vienna Austria. http://www.R-project. org/.

Roessiger, J, Griess V. C., Härtl, F., Clasen, C., Knoke, T., 2013: How economic performance of a stand increases due to decreased failure risk associated with the admixing of species. Ecological Modelling, 255:58-69.

Roessiger, J., Ficko, A., Clasen, C., Griess, V. C., Knoke, T., 2016: Variability in growth of trees in uneven-aged stands displays the need for optimizing diversified harvest diameters. European Journal of Forest Research, 135:283-295.

Roessiger, J., Kulla, L., Bošela, M., 2018: Finding equilibrium in continuous-cover forest management sensitive to interest rates using an advanced matrix transition model. Journal of Forest Economics, 33:83-94.
Rowan, T., 1990: Functional Stability Analysis of Numerical Algorithms. Ph.D. Thesis. Department of Computer Sciences, University of Texas at Austin.

Seidl, R., Schelhaas, M. J., Rammer, W., Verkerk, P. J., 2014: Increasing forest disturbances in Europe and their impact on carbon storage. Nature Climate Change, 4:806-810.

Šimůnek, V., Vacek, Z., Vacek, S., Králíček, I., Vančura, K., 2019: Growth variability of European beech (Fagus sylvatica L.) natural forests: Dendroclimatic study from Krkonoše National Park. Central European Forestry Journal, 65:92-102.

Solomon, D. S., Hosmer, R. A., Hayslett, H. T. J., 1986: A two-stage matrix model for predicting growth of forest stands in the Northeast. Canadian Journal of Forest Research, 16:521-528.

Usher, M. B., 1969: A matrix model for forest management. Biometrics, 25:309-315.

Vacek, Z., Vacek, S., Slanař, J., Bílek, L., Bulušek, D., Štafančík, I. et al., 2019: Adaptation of Norway spruce and European beech forests under climate change: from resistance to close-to-nature silviculture. Central European Forestry Journal, 65:129-144. 